\title{
Ketahanan Pangan Berbasis Sumberdaya Lokal : Konsumsi Pangan dan Status Gizi pada Penduduk Asli di Wilayah Bantaran Sungai dan Non Bantaran Sungai, Kalimantan Timur
}

\section{(Food Security The Basis of Local Resource : Food Consumption and Nutritional Status at Indigenous People Household Living in The Area of Lower River Line and Upper River Line Area, East Kalimantan)}

\author{
Ahmad Suhaimi \\ Program Studi Agribisnis, Sekolah Tinggi Ilmu Pertanian Amuntai \\ ahmad99ec@gmail.com
}

\begin{abstract}
ABSTRAK
Penelitian ini bertujuan untuk mengetahui tingkat konsumsi energi dan status gizi pada rumah tangga penduduk asli yang bermukim di bantaran sungai Mahakam, faktor-faktor sosial-budaya, dan ekonomi yang berhubungan dengan konsumsi pangan rumah tangga. Hasil penelitian menunjukkan ratarata konsumsi energi dan protein per orang adalah 2.000,7 kkal dan 71,0 gram dimana tingkat konsumsi energi aktual adalah 100,04\% dan tingkat konsumsi protein aktual adalah 136,5\%. Nilai tingkat konsumsi energi aktual berada dalam kategori baik ((> 100\% dari AKG) dan tingkat konsumsi protein aktual berada dalam kategori baik (> 100\% dari AKG). Ketika status gizi anak-anak balita terkait dengan energi tingkat konsumsi rumah tangga, prevalensi gizi buruk berada pada kategori rendah dan defisit untuk tingkat konsumsi energi rumah tangga, dan status gizi yang baik cenderung berada pada kategori cukup dan baik untuk tingkat konsumsi energi rumah tangga. Perkiraan tersebut juga didukung oleh Korelasi Pearson $p$ $=0,0001$ dan $r=0,692$. Dapat dipahami hubungan keduanya sangat signifikan antara status gizi balita dan tingkat konsumsi energi rumah tangga, sosial budaya, faktor ekonomi yang mempengaruhi konsumsi makanan rumah tangga adalah : kesadaran gizi ibu $(p=0,016)$, preferensi makanan $(p=0,023)$, penghindaran makanan $(p=0,000)$, ketimpangan anggota rumah tangga $(p=0,000)$, dan tingkat pendapatan rumah tangga $(p=0,001)$.
\end{abstract}

Kata kunci: Makanan, konsumsi, gizi, status, orang.

\section{ABSTRACT}

The research aimed to examine food consumption and nutritional status in the household of indigenous people "Dayak" which resided at the low line of Mahakam river, and to conduct the study on social, culture, and economic factors which affected the food consumption. The research result showed average energy and protein consumption per person was 2.000,7 kcal and 71,0 gram which the actual energy consumption level was 100,04\% and actual protein consumption level was 136,5\%. The value of actual energy consumption level was in the good category $((>100 \%$ of RDA) and actual protein consumption level was in the good category (>100\% of RDA). When the nutritional status of children under five was related to energy consumption level of household, the prevalence of malnutrition was in the low and deficit category for energy consumption level of household; and the good nutritional status tended to be in the sufficient and good category for energy consumption level of household. The estimation was also supported by the Pearson Correlation of $p=0.0001$ and $r=0.692$. It could be understood their was highly significant relationship of nutritional status of children under five and the energy consumption level of household. The socio-culture, economic factors which affected food consumption of household were : nutritional awareness of mother $(p=0.016)$, food preference $(p=0.023)$, food avoidance $(p=0.000)$, inequality of member in the household $(p=0.000)$, and income level of household $(p=0.001)$.

Keywords : Food, consumption, nutrition, status, people.

\section{PENDAHULUAN}

Disparitas konsumsi pangan pada individu, kelompok masyarakat, dan antar desa-kota sangat nyata di Indonesia (data BPS,
2002) yang disebabkan oleh kemiskinan, rendahnya pendidikan, dan kepercayaan yang terkait dengan tabu terhadap makanan (Rimbawan, 2004). Belum tercukupinya kualitas dan jumlah pangan yang dikonsumsi 
pada sebagian masyarakat akan berdampak pada rendahnya tingkat kesehatan dan produktivitas nasional.

Disparitas konsumsi pangan tersebut seperti yang terjadi di Kalimantan Timur, yaitu rata-rata konsumsi kalori dan protein per kapita per hari pada penduduk perkotaan masing-masing adalah 2.026,50 kilo kalori dan 59,05 gram, sangat berbeda dengan masyarakat perdesaan masing-masing adalah 1.792,30 dan 48,84 gram (BPS, 2002). Menurunnya konsumsi pangan pada sebagian penduduk asli di Kabupaten Kutai Kartanegara Kalimantan Timur akibat ketersediaan sumber daya pangan di hutan dan di perairan semakin berkurang dengan maraknya pembukaan lahan untuk $\mathrm{HPH}$, perkebunan kelapa sawit, dan tambang batubara. Kondisi ini berdampak meningkatnya prevalensi gizi buruk pada balita sebagai obyek yang paling rawan terhadap ketahanan pangan rumah tangga. Diperparah lagi penduduk asli masih mempraktekkan pola pantangan makan. Makanan dan minuman yang dipantangkan dianggap dapat mengganggu kesehatan jasmani, dan juga karena alasan agama (Suhaimi, 2003).

Penduduk asli di Kabupaten Kutai Kartanegara adalah suku dayak memiliki kekayaan sosial-budaya yang unik menyenangi bermukim di bantaran sungai Mahakam. Sungai digunakan sebagai kegiatan ekonomi seperti tempat jual-beli, sarana transportasi, juga sebagai sumber untuk memenuhi kebutuhan protein hewani dari berbagai jenis ikan konsumsi. Sungai mahakam sebagai sarana vital kehidupan yang airnya bersumber dari hutan-hutan di Tanah Hulu Kalimantan Timur.

Perbedaan budaya penduduk asli yang menyenangi tinggal di bantaran Sungai Mahakam menciptakan perbedaan konsumsi pangan rumah tangga, pola konsumsi, kebiasaan makan dan pantangan makan jika dibandingkan dengan masyarakat yang bermukim di non bantaran sungai. Perbedaan tampak misalnya orang dayak yang tinggal di bantaran sungai mahakam mengkonsumsi ikan air tawar relatif lebih banyak dan makan ikan tidak hanya untuk memenuhi kebutuhan gizi, tetapi lebih jauh sebagai kebutuhan status sosial.

Penelitian ini bertujuan untuk mengetahui tingkat konsumsi energi dan status gizi pada rumah tangga penduduk asli yang bermukim di bantaran sungai Mahakam, faktor-faktor sosial-budaya, dan ekonomi yang berhubungan dengan konsumsi pangan rumah tangga.

\section{METODA PENELITIAN}

\section{Desain Penelitian dan Unit Analisis}

Metoda yang digunakan dalam penelitian ini adalah metoda survei dengan teknik potong lintang (cross sectional) dan in depth study, melalui kombinasi antara analisis kuantitatif dan kualitatif. Unit analisis yang diteliti adalah rumah tangga penduduk asli (indigenous people) "Dayak" yang yang bermukim di bantaran sungai Mahakam. Penelitian dilaksanakan di Kabupaten Kutai Kartanegara Propinsi Kalimantan Timur selama satu tahun terhitung mulai bulan Maret 2011 - Agustus 2012.

\section{Populasi dan Sampel}

Pemilihan Kecamatan, kelurahan, dan desa dilakukan dengan metoda acak sederhana (simple random sampling) dan pemilihan rumah tangga contoh (sampel) dilakukan juga dengan metoda acak sederhana (simple random sampling) dari sejumlah sampel yang dianggap mampu merepresentasikan populasi penduduk asli yang bermukim di bantaran sungai mahakam.

Pemilihan rumah tangga untuk menggali informasi mendalam dilakukan indepth study secara purposive rasional dengan mempertimbangkan kondisi sosial-ekonomi dan kesehatan (ukuran keluarga, tingkat pendapatan, dan status gizi anak Balita). Sebaran contoh penelitian seperti terlihat pada Tabel 1.

\section{Prosedur Pengumpulan Data}

Jenis data yang dikumpulkan meliputi : (1) identitas responden (nama, nomer urut KK), (2) faktor-faktor sosial (ukuran keluarga, pendidikan kepala keluarga, pengetahuan gizi ibu), faktor-faktor budaya (preferensi terhadap bahan pangan, pantangan makan), faktor- 
faktor ekonomi (pendapatan keluarga, pengeluaran pangan).

Penentuan konsumsi pangan rumahtangga secara kualititif dan kuantitatif menggambarkan jenis, frekuensi dan banyaknya pangan dikonsumsi dengan menggunakan metode food recall 24 jam. Pengukuran status gizi anak Balita dilakukan dengan antropometrik, mengukur berat badan anak terhadap umur $(\mathrm{BB} / \mathrm{U})$, dengan asumsi bahwa berat badan anak dalam pertumbuhan adalah labil, maka indeks BB/U lebih menggambarkan status gizi seseorang saat ini (current nutritional status), (Supariasa, 2002).
Data dan informasi yang bersifat kualitatif yang mempengaruhi konsumsi pangan, dan status gizi dikumpulkan dengan wawancara mendalam (in depth study) dengan menggunakan pedoman wawancara.

\section{Analisis Data}

Data konsumsi pangan (recall 24 jam) yang diperoleh dalam penelitian ini diolah dan dianalisis dengan program World Food, 2.0 (California University Davis, 1996), dan dibandingkan dengan Angka Kecukupan Gizi (AKG) dan skor PPH.

Tabel 1. Sebaran Contoh Penelitian

\begin{tabular}{llllc}
\multicolumn{1}{c}{ Lokasi } & Kecamatan & \multicolumn{1}{c}{ Desa } & Populasi & $\begin{array}{c}\sum \text { Rumah Tangga } \\
\text { (sample) }\end{array}$ \\
\hline Kabupaten & Tenggarong & - Loa Ulung & 410 & $41(3)^{*}$ \\
Kutai & Seberang & - Loa Raya & 335 & $34(3)^{*}$ \\
Kartanegara & & - Loa Pari & 327 & $33(3)^{*}$ \\
& & - Perjiwa & 339 & $34(3)^{*}$ \\
\hline \multicolumn{1}{c}{ Jumlah } & & & $142(24)^{*}$ \\
\hline
\end{tabular}

Ket : (3)* In depth study

Data antropometrik balita yang diperoleh dibandingkan dengan standar WHO dan NCHS untuk memperoleh nilai z-score dengan bantuan program EpiInfo 6.0. Indikator yang digunakan berdasarkan $\mathrm{BB} / \mathrm{U}$, dengan cut of point : gizi buruk (jika < -3 SD), gizi kurang (jika $-3.00 \mathrm{~s} / \mathrm{d}-2.00 \mathrm{SD}$ ), gizi baik (jika $-2.00 \mathrm{~s} / \mathrm{d}+2.00 \mathrm{SD}$ ), gizi lebih (jika $\geq$ 2.00 SD).

Data faktor-faktor sosial-budaya, dan ekonomi yang berhubungan dan mempengaruhi konsumsi pangan dan status gizi dianalisis secara deskriptif. Selanjutnya data dianalisis melalui tiga tahapan, yaitu analisis univariate, bivariate dan multivariate dengan memanfaatkan paket program the
Statistical Product and Service Solutions (SPSS) versi 14,0.

\section{HASIL}

\section{Konsumsi Energi dan Protein Rumah} Tangga

Hasil recall 24 jam pada rumah tangga menunjukkan konsumsi energi dan protein rata-rata adalah 2.000,7 kkal dan 71,0 gram. Nilai TKE berada pada kategori "baik" yaitu yaitu $\geq 100$ persen dari AKG dan tingkat konsumsi protein juga berada pada kategori baik yaitu $\geq 100$ persen $\mathrm{AKG}$, seperti terlihat pada tabel 2 berikut ini. 
Tabel 2. Distribusi Responden Berdasarkan Kategori Tingkat Konsumsi Energi dan Protein di Wilayah Bantaran Sungai Mahakam

Jumlah Rumah Tangga (\%)

\begin{tabular}{|c|c|c|c|c|c|}
\hline \multirow{3}{*}{ No } & \multirow{3}{*}{ Kategori } & \multirow{2}{*}{\multicolumn{2}{|c|}{$\begin{array}{l}\text { Konsumsi Energi } \\
(\% 2000 \mathrm{kkal})^{*}\end{array}$}} & \multirow{2}{*}{\multicolumn{2}{|c|}{$\begin{array}{l}\text { Konsumsi Protein } \\
\text { (\% } 52 \text { gram })^{*}\end{array}$}} \\
\hline & & & & & \\
\hline & & $\mathrm{N}$ & $\%$ & $\mathrm{~N}$ & $\%$ \\
\hline 1. & $: \geq 100 \% \mathrm{AKG}$ & 110 & 77.5 & 123 & 86,6 \\
\hline 2. & $: 80-99 \% \mathrm{AKG}$ & 24 & 16.9 & 14 & 9,9 \\
\hline 3. & Kurang AKG $: 70-80 \%$ & 7 & 4.9 & 3 & 2,1 \\
\hline \multirow[t]{2}{*}{4.} & $:<70 \% \mathrm{AKG}$ & 1 & 0.7 & 2 & 1,4 \\
\hline & & 142 & 100 & 142 & 100 \\
\hline
\end{tabular}

Sumber : Hasil Analisis, 2008. *WNPG VIII (2004).

Analisis Konsumsi Pangan Berdasarkan Pola Pangan Harapan (PPH)

Situasi konsumsi dan keragaman pangan pada wilayah permukiman bantaran sungai ini menunjukkan kondisi sedang, yaitu $2.000,7$ kkal atau pencapaiannya 100,04 persen dari AKG dengan skor PPH hanya 85.6.

Faktor-Faktor Yang Berhubungan dengan Konsumsi Pangan Rumah Tangga

Faktor sosial yang berhubungan dengan konsumsi pangan adalah pengetahuan pangan dan gizi ibu, sedangkan ukuran keluarga dan pendidikan kepala keluarga tidak berpengaruh secara signifikan. Sebanyak lima faktor budaya yang dijadikan prediktor terhadap konsumsi pangan rumah tangga, hanya tiga faktor yang berpengaruh secara signifikan yaitu : preferensi terhadap bahan pangan, kepercayaan pada tradisi, dan prioritas makan. Faktor ekonomi, yaitu tingkat pendapatan berpengaruh signifikan terhadap konsumsi pangan rumah tangga, seperti terlihat pada Tabel 3. berikut.

Tabel 3. Analisis Multivariate Faktor-Faktor Sosial-Budaya, dan Ekonomi Yang Mempengaruhi Konsumsi Pangan Rumah Tangga Pada Penduduk Asli

\begin{tabular}{|c|c|c|c|c|}
\hline \multirow[b]{2}{*}{ No } & \multirow{2}{*}{ Faktor-Faktor Sosial, Budaya, Ekonomi } & \multicolumn{3}{|c|}{ Koefisien } \\
\hline & & $\beta$ & $\mathrm{t}$ & $\mathrm{P}$ \\
\hline \multirow[t]{4}{*}{1.} & Faktor Sosial : & & & \\
\hline & a. Ukuran Keluarga & -21.278 & -1.214 & 0.227 \\
\hline & b. Pendidikan kepala keluarga & 9.724 & 0.908 & 0.365 \\
\hline & c. Pengetahuan gizi ibu & 6.231 & 2.435 & 0.016 \\
\hline \multirow[t]{7}{*}{2.} & Faktor Budaya: & & & \\
\hline & a. Prefeperensi & 4.430 & 2.305 & 0.023 \\
\hline & b. Pantangan Makan & & & \\
\hline & - Kepercayaan Pada Tradisi & 13.688 & 3,776 & 0.000 \\
\hline & - Status dalam Keluarga & 23.565 & 7,298 & 0.000 \\
\hline & - Kepercayaan Sehat-Sakit & 6.679 & 0.148 & 0.882 \\
\hline & - Asosiasi Emosional & 39.227 & 1,813 & 0.074 \\
\hline \multirow[t]{2}{*}{3.} & Faktor Ekonomi : & & 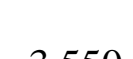 & 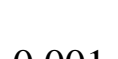 \\
\hline & a. Tingkat Pendapatan Kepala Keluarga & -0.002 & -3.550 & 0.001 \\
\hline
\end{tabular}

Sumber : Hasil Penelitian, 2012

\section{$\underline{\text { Status Gizi }}$}

Status gizi baik dari 142 anak balita pada rumah tangga di wilayah bantaran sungai adalah sebesar 74,7 persen, gizi kurang sebesar 19,7 persen, prevalensi gizi buruk sebesar 4,9 persen, dan anak balita yang berstatus gizi lebih ditemukan satu orang $(0,7$ persen). Berdasarkan kelompok umur, prevalensi gizi buruk pada balita berumur antara 24-59 bulan, atau kondisi ini terjadi pada kelompok umur di atas 23 bulan. Penderita gizi kurang ditemukan pada semua 
kelompok umur, sedangkan anak balita yang berstatus gizi lebih hanya ditemukan pada kelompok umur 24-35 bulan. Hasil penelitian seperti ditunjukkan pada Tabel 4. berikut.

Tabel 4. Distribusi Status Gizi Balita Berdasarkan Kelompok Umur di Wilayah Bantaran Sungai Mahakam

\begin{tabular}{|c|c|c|c|c|c|c|c|c|c|c|c|c|}
\hline \multirow{3}{*}{ Status Gizi } & \multicolumn{12}{|c|}{ Kelompok Umur (Bulan) } \\
\hline & \multicolumn{2}{|c|}{$6-11$} & \multicolumn{2}{|c|}{ 23-Dec } & \multicolumn{2}{|c|}{$24-35$} & \multicolumn{2}{|c|}{$36-47$} & \multicolumn{2}{|c|}{$48-59$} & \multicolumn{2}{|c|}{ Total } \\
\hline & $\mathrm{N}$ & $\%$ & $\mathrm{~N}$ & $\%$ & $\mathrm{~N}$ & $\%$ & $\mathrm{~N}$ & $\%$ & $\mathrm{~N}$ & $\%$ & $\mathrm{~N}$ & $\%$ \\
\hline Gizi Buruk & 0 & 0 & 0 & 0 & 3 & 2.1 & 3 & 2.1 & 1 & 0.7 & 7 & 4.9 \\
\hline Gizi Kurang & 2 & 1.4 & 12 & 8.5 & 7 & 4.9 & 1 & 0.7 & 6 & 4.2 & 28 & 19.7 \\
\hline Gizi Baik & 22 & 15.5 & 37 & 26.1 & 27 & 19 & 15 & 10.6 & 5 & 3.5 & 106 & 74.7 \\
\hline Gizi Lebih & 0 & 0 & 0 & 0 & 1 & 0.7 & 0 & 0 & 0 & 0 & 1 & 0.7 \\
\hline Jumlah & 23 & 16.2 & 47 & 33.1 & 41 & 28.9 & 19 & 13.4 & 12 & 8.5 & 142 & 100 \\
\hline
\end{tabular}

Sumber : Hasil Penelitian, 2012

Dapat dijelaskan juga, pada kelompok umur 6 - 11 bulan ditemukan KEP sebesar 1,4 persen dan setelah umur diatas 12 bulan terlihat tingginya kecenderungan balita mengalami KEP.

Jika status gizi balita dihubungkan dengan konsumsi energi rumah tangga, hasil analisis menunjukkan bahwa rumah tangga dengan kategori tingkat konsumsi energi "baik" tidak terdapat balita penderita gizi kurang bahkan penderita gizi buruk, pada strata ini balita dengan status gizi baik sebesar 15,5 persen, dan status gizi lebih sebesar 0,7 persen.

Rumah tangga dengan kategori tingkat konsumsi energi "sedang" juga tidak ditemukan balita dengan penderita status gizi buruk dan status gizi lebih, namun terdapat sebesar 19,0 persen balita menderita gizi kurang. Di antara empat kategori tingkat konsumsi energi, pada kategori "sedang" paling banyak didapatkan balita dengan status gizi baik yaitu sebesar 58,5 persen.

Tingkat konsumsi energi pada rumah tangga dengan kategori "kurang" terdapat balita dengan penderita status gizi buruk sebesar 4,2 persen dan status gizi kurang 1,4 persen, dan tidak ditemukan balita dengan status gizi baik dan status gizi lebih. Di antara empat kategori tingkat konsumsi energi pada kategori "kurang" paling banyak didapatkan balita dengan status gizi buruk yaitu sebesar 4,2 persen.

Rumah tangga dengan kategori tingkat konsumsi energi "defisit" terdapat satu orang balita $(0,7$ persen) dengan status gizi buruk, sedangkan balita penderita gizi kurang, status gizi baik, dan status gizi gizi lebih sama sekali tidak ditemukan pada kategori ini, seperti terlihat pada Tabel 5 .

Tabel 5. Status Gizi Balita Berdasarkan Kategori Tingkat Konsumsi Energi

\begin{tabular}{lcccccccccc}
\hline & \multicolumn{8}{c}{ Tingkat Konsumsi Energi } \\
\cline { 2 - 12 } Status Gizi & $\begin{array}{c}\text { Baik } \\
>100 \%\end{array}$ & $\begin{array}{c}\text { Sedang } \\
\text { AKG-99\% AKG }\end{array}$ & $\begin{array}{c}\text { Kurang } \\
70-80 \% \\
\text { AKG }\end{array}$ & $\begin{array}{c}\text { Defisit } \\
<70 \% \\
\text { AKG }\end{array}$ & \multirow{2}{*}{ Total } \\
\cline { 2 - 14 } & $\mathrm{N}$ & $\%$ & $\mathrm{~N}$ & $\%$ & $\mathrm{~N}$ & $\%$ & $\mathrm{~N}$ & $\%$ & $\mathrm{~N}$ & $\%$ \\
\hline Gizi Lebih & 1 & 0.7 & 0 & 0 & 0 & 0 & 0 & 0 & 1 & 0.7 \\
Gizi Baik & 23 & 15.5 & 83 & 58.5 & 0 & 0 & 0 & 0 & 106 & 75 \\
Gizi Kurang & 0 & 0 & 26 & 19 & 2 & 1.4 & 0 & 0 & 28 & 20 \\
Gizi Buruk & 0 & 0 & 0 & 0 & 6 & 4.2 & 1 & 0.7 & 7 & 4.9 \\
Jumlah & 24 & 16.2 & 109 & 77.5 & 8 & 5.6 & 1 & 0.7 & 142 & 100 \\
\hline
\end{tabular}

Sumber : Hasil Penelitian, 2012 


\section{Pembahasan}

\section{Konsumsi Energi dan Protein Rumah Tangga}

Konsumsi energi rata-rata rumah tangga penduduk asli sebesar 2.000,7 kkal, jika dibandingkan dengan data Susenas (BPS, 2002) nilai ini berada di atas konsumsi energi tingkat provinsi Kalimantan Timur $(1.918,47$ kkal) dan juga berada di atas konsumsi energi tingkat nasional (1.985.73 kkal). Sedangkan konsumsi protein rata-rata sebesar 71,0 gram berada di atas konsumsi protein tingkat provinsi Kalimantan Timur (54,58 gram) dan juga berada di atas konsumsi protein tingkat nasional $(54,42$ gram).

Jika dibandingkan dengan Angka Kecukupan Gizi berdasarkan Widyakarya Nasional Pangan dan Gizi VIII (2004) merekomendasikan untuk energi 2000 kkal dan protein 52 gram, maka tingkat konsumsi energi (TKE) aktual adalah 100,04 persen dan tingkat konsumsi protein aktual adalah 136,5 persen. Tingkat konsumsi energi ini berada pada kategori "baik", namun konsumsi per rumah tangga masih terdapat (4,9 persen) dengan kategori kurang dan defisit sebanyak (0,7persen). Dan konsumsi protein berada pada kategori "baik", namun masih terdapat kategori kurang sebesar 2,1 persen, dan kategori defisit sebesar 1,4 persen.

Konsumsi protein tinggi, hal ini berkaitan dengan persfektif tentang " Kebiasaan Makan Ikan Air Tawar". Kebiasaan makan ikan air tawar menduduki superioritas diantara jenis pangan yang lain, dan lebih jauh sebagai keberadaan status sosial dan nilai kebersamaan dalam kelompok masyarakat adat. Persfektif ini merupakan resultan dari adaftasi ekologis penduduk asli, lingkungan perairan sungai dengan sumberdaya ikan dimanfaatkan untuk pemenuhan konsumsi pangan sumber protein hewani sehari-hari, yang akhirnya terkondisi menjadi selera (preferensi).

Menurut persepektif orang dayak pemanfaatan sumberdaya hutan dan sungai adalah sebagai pilihan hidup, keberadaan sumberdaya ini harus dilestarikan turun- temurun. Tanah, sungai, dan hutan adalah tiga elemen terpenting yang memungkinkan seseorang hidup sebagai orang dayak sejati. Selama berabad-abad, tiga elemen ini telah membentuk sebuah identitas unik yang kita kenal sekarang sebagai orang dayak, kebudayaan dayak, hukum adat dayak dan kepercayaan dayak."

Pertanian dan kehutanan merupakan sumber penting bagi ketahanan pangan masyarakat. Berbagai hasil hutan dapat dijadikan sumber pangan yang dapat dimanfaatkan langsung dan dijual (Wijaya et. al., 2005). Dahulu, pengambilan sumberdaya alam dilakukan hanya untuk memenuhi kebutuhan pokok atau bersifat subsisten. Meskipun pada umumnya sistem barter dan pasar telah lama dikenal masyarakat, jauh lebih lama dari yang kita duga (Levang et. al., 2005 dalam Wijaya et. al., 2005).

Sungai selain digunakan sebagai sarana transportasi, kegiatan ekonomi seperti tempat jual-beli, juga sebagai sumber pangan dari berbagai jenis ikan konsumsi. Sungai Mahakam sebagai sarana vital kehidupan yang airnya bersumber dari hutan-hutan di Tanah Hulu, Kalimantan Timur. Adanya anak-anak sungai (sub DAS) yang berada di wilayah hutan yang menghubungkan dengan sungai utama, anak-anak sungai ini kaya dengan jenis ikan air tawar (seperti : ikan Gabus, Baung, Betok, Sepat, Jelawat, Lais, dan Nilem) dan sekaligus sebagai tempat reproduksi ikan secara alami (Suhaimi, 2003).

\section{Analisis Konsumsi Pangan Berdasarkan Pola Pangan Harapan (PPH)}

Tingkat konsumsi energi rumah tangga sudah mencapai 100,04 persen, tetapi kualitas dan keragamannya belum menunjukkan kondisi konsumsi yang ideal, yaitu : (i) kelebihan konsumsi pada komoditas padi-padian, pangan hewani, dan gula ; (ii) kurang pada minyak/lemak, kacang-kacangan, buah/biji berminyak, sayur dan buah, kelompok lain-lain.

\section{Faktor-Faktor Yang Berhubungan Dengan Konsumsi Pangan Rumah Tangga}


Distribusi rumah tangga berdasarkan ukuran keluarga dan tingkat konsumsi energi pada rumah tangga penduduk asli menunjukkan adanya kecenderungan dengan bertambahnya ukuran keluarga berdampak konsumsi energi akan berkurang. Distribusi pangan di dalam rumah tangga merupakan suatu sistem yang komplek. Terdapat faktor eksternal seperti kebudayaan dan faktor internal seperti ukuran keluarga, yang mempengaruhi distribusi pangan di dalam rumah tangga (Rogers dan Schlosman dalam Den Hartog, Van Staveren dan Brouwer, 1995).

Tingkat pendidikan kepala keluarga pada penduduk asli didominasi hanya tamat sekolah dasar. Tingkat pendidikan ini cenderung berhubungan dengan konsumsi energi, semakin tinggi tingkat pendidikan kepala keluarga maka semakin mudah untuk mengadopsi pengetahuan pangan dan gizi melalui media elektronik maupun media cetak. Menurut Niehof (1988) dalam Den Hartog, Van Staveren dan Brouwer, 1995 , tingkat pendidikan kepala keluarga berkaitan erat dengan wawasan pengetahuan mengenai sumber-sumber gizi dan jenis-jenis makanan yang dikandungnya yang baik untuk konsumsi keluarga.

Disribusi rumah tangga berdasarkan tingkat konsumsi energi dan pengetahuan gizi ibu menunjukkan adanya kecenderungan dengan tingginya pengetahuan pangan dan gizi ibu berdampak konsumsi energi akan lebih baik. Dan meskipun sebagian rumah tangga mempraktekkan berpantang makan sebagai alasan budaya, namun ibu-ibu rumah tangga sangat membantu untuk tersedianya makanan memenuhi norma gizi. Antar rumah tangga dan keluarga saling berinteraksi dalam hukum adat yang difasilitasi oleh tempat-tempat pertemuan non formal (rumah, balai) untuk membicarakan bercocok tanam dan mengolah makanan.

Berdasarkan hasil uji statistik korelasi pearson, menunjukkan hubungan yang sangat bermakna antara keragaman jenis pangan yang dimakan dengan jumlah energi yang dikonsumsi rumah tangga $(\mathrm{p}=0,000, \mathrm{r}$ = 696). Hukum adat mengharuskan orang dayak untuk hidup tolong menolong dan saling tenggang rasa serta peduli pada anggota keluarga baik dalam kelompok maupun di luar kelompok masyarakat adat. Nilai kolektifitas pada hukum adat ini sangat dijunjung tinggi dan merupakan unsur kearifan budaya terhadap pemanfaatan sumberdaya hutan. Fenomena tolongmenolong dalam menyikapi kepedulian sesama untuk mendistribusikan pangan lokal yaitu dengan sikap saling bertukar hasil panen pertanian atau saling memberi. Kondisi ini merupakan sebuah sikap untuk mendistribusikan pangan dan menganekaragamkan konsumsi pangan antar anggota kelompok orang dayak. Nilai-nilai budaya ini mempunyai kemiripan dengan hasil penelitian Bulkis (2004), bahwa nilai-nilai kolektivitas di wilayah perdesaan Sulawesi Selatan masih ditemukan, dan kebiasaan tolong-menolong merupakan salah satu bentuk mengatasi rawan pangan (coping mechanism). Dan coping mechanism berhubungan dengan sistem sosial-budaya yang berlaku di masyarakat.

Konsumsi bahan pangan dengan kategori sangat menyukai pada penduduk asli lebih berorientasi pada alasan selera, mereka lebih mempertahankan mengkonsumsi bahan pangan berasal dari sumberdaya lokal. Dan makanan sebagai sumberdaya lokal tersedia di masyarakat sebagai realitas sosial, diinternalisasi dari lingkungan ke individu, ke keluarga (di praktekkan oleh orang tua, kakek dan nenek), dan ke masyarakat yang akhirnya melahirkan selera. Sanjur (1982), menyatakan bahwa sikap terhadap pangan terutama preferensi mempengaruhi komsumsi pangan. Dan berdasarkan model seleksi pangan yang dikembangkan oleh Ellis et. al., dalam Sanjur, (1982) dan King et. al., (1983) maka faktor-faktor yang mempengaruhi preferensi pangan berpusat pada karakteristik individu, lingkungan dan pangan itu sendiri.

Sebesar $59,86 \%$ penduduk asli mempercayai dan mempraktekkan pantangan makan dengan tingkat rasionalitas sebesar $28,24 \%$. Pantangan makan lebih berorientasi kepercayaan kepada adat yaitu sebesar $31,69 \%$. Praktek pantangan ini berdampak membatasi jumlah energi yang dikonsumsi 
dan membatasi distribusi pangan dalam rumah tangga. Pantangan makan ternyata berpengaruh sangat nyata terhadap konsumsi energi rumah tangga.

Prioritas makanan dalam rumah tangga bervariasi, namun prioritas tertinggi adalah dibagi rata dengan nilai $58,45 \%$ dan prioritas terendah diberikan kepada anak dengan nilai hanya $10,56 \%$. Kebiasaan mempraktekkan prioritas makan sangat menentukan distribusi pangan dalam rumah tangga yang selanjutnya berdampak pada tingkat konsumsi pangan dan status gizi anggota rumah tangga.

Distribusi rumah tangga penduduk asli berdasarkan tingkat pendapatan dan konsumsi energi menunjukkan adanya kecenderungan dengan naiknya pendapatan rumah tangga berdampak konsumsi energi juga akan bertambah, hal ini didukung oleh analisis korelasi Pearson menunjukkan adanya hubungan yang bermakna dengan nilai $(p=0,000, r=0,619)$. Dan hasil analisis multivariate menunjukkan bahwa peubah bebas "tingkat pendapatan" ini berpengaruhi sangat nyata terhadap jumlah konsumsi energi rumah tangga dengan nilai $\mathrm{p}=0,001$ dan $\mathrm{t}=-3,550$.

Usaha pemenuhan pangan rumah tangga sebelumnya sangat bergantung dengan memanfaatkan sumberdaya hutan dan sungai, hasilnya lebih banyak langsung dikonsumsi oleh rumah tangga. Hasil hutan dan sungai dapat memberikan penghidupan yang layak, namun sekarang berubah, hasil sumberdaya hutan semakin menurun dengan adanya desakan pembukaan areal penebangan kayu dengan HPH, areal budidaya kelapa sawit, tambang batubara. Selain itu wilayah bantaran sungai mengalami abrasi akibat ombak besar dari kapal tanker pengangkut batubara yang berlalu lalang tiap hari yang merusak jalanjalan utama di wilayah perdesaan, dan menimbulkan pencemaran dari buangan air panas, dan debu batubara yang menghambat kelestarian sumberdaya ikan dan biota air lainnya.

Pendapatan rumah tangga dalam bentuk natura berupa hasil pangan dan hasil hutan sangat menurun. Padahal manfaat yang diterima penduduk asli lebih besar dengan sistem pengelolaan lingkungan secara tradisional dibandingkan dengan mekanisasi pertanian. Kajian ekonomi lingkungan dari NRM/EPIQ dan Konsorsium SHK Kal-Tim (2000) menyimpulkan dari perspektif masyarakat lokal, hasil sistem pengelolaan hutan tradisional memberikan pendapatan bagi tenaga kerja lebih tinggi dari pada perkebunan kelapa sawit, walaupun tanpa memperhitungkan manfaat dan biaya tidak berwujud yang diperoleh dari sistem ini.

Hubungan antara tingkat pendapatan dengan proporsi pengeluaran pangan adalah berbanding terbalik ditunjukkan hasil uji statistik korelasi Pearson dengan nilai $\mathrm{p}=$ 0,000 dan $r=-0,375$. Meningkatnya pendapatan rumah tangga cenderung akan menambah jumlah pangan dikonsumsi ditunjukkan dengan meningkatnya konsumsi energi per kapita. Meningkatnya jumlah energi yang dikonsumsi tidak hanya menambah konsumsi pangan, tetapi juga dengan menambah keragaman konsumsi pangan. Makin tinggi daya beli rumah-tangga maka makin beranekaragam pangan yang dikonsumsi, makin banyak pangan yang dikonsumsi memiliki nilai gizi tinggi. Salah satu alasan penting yang menyebabkan konsumsi pangan rumah-tangga lebih beragam adalah peningkatan pendapatan rumah-tangga. Dan terdapat hubungan antara konsumsi pangan (energi dan protein) dengan status ekonomi rumah tangga dan status gizi masyarakat, Suhardjo (1992).

\section{Status Gizi}

Jika dihubungkan dengan tingkat konsumsi energi rumah tangga, prevalensi gizi buruk balita berada pada kategori TKE rumah tangga "kurang dan defisit" dan status gizi baik balita kecenderungan berada pada kategori TKE rumah tangga "sedang dan baik". Dan estimasi ini juga didukung oleh uji statistik korelasi Pearson yang ditunjukkan nilai $p=0,000$ dengan $r=0,692$, hal ini dapat dipahami adanya hubungan sangat bermakna antara status gizi balita dengan tingkat konsumsi energi rumah tangga. 


\section{KESIMPULAN}

Konsumsi energi dan protein rata-rata rumah tangga penduduk asli adalah 2.000,7 kkal dan 71,0 gram dengan nilai TKE pada kategori "baik" ( $\geq 100 \%$ AKG) dan tingkat konsumsi protein juga pada kategori baik $(\geq$ $100 \%$ AKG). Praktek pantangan makan di dalam masyarakat adat dapat membatasi distribusi dan keragaman konsumsi pangan rumah tangga. Adanya hubungan antara status gizi balita dengan tingkat konsumsi energi rumah tangga, prevalensi gizi buruk balita berada pada kategori TKE rumah tangga "kurang dan defisit" dan status gizi baik cenderung berada pada kategori TKE rumah tangga "sedang dan baik". Menurunnya konsumsi pangan penduduk asli karena berkurangnya sumber pangan di hutan dan di sungai akibat pembukaan lahan yang berdampak pada menurunnya status gizi masyarakat (gizi balita).

\section{DAFTAR PUSTAKA}

Bulkis, S. 2004. Ketahanan pangan rumah tangga. kajian sosiologis rumah tangga sebagai sistem sosial pada tiga tipe agroekosistem di Kabupaten Sinjai, Sulawesi Selatan. Disertasi UNHAS, Makassar.

BPS. 2002. Konsumsi Kalori dan Protein Penduduk Indonesia dan Propinsi. BPS RI. Jakarta.

Den Hartog, A.P. and W.A. van Staveren and Brouwer, I.D. 1995. Manual for Sosial Surveys on Food Habits and Consumption in Developing Countries. Margraf Verlag : Weikersheim.
King, M.H., F..M..A. King, D.C, H.J.L. Burgess dan A.P. Burgess. 1983. Nutrition for Developing Countries. Oxford University Press, Dar es Salaam.

NRM/EPIQ dan Konsorsium SHK Kal-Tim. 2000. Valuasi sistem pengelolaan hutan secara tradisional oleh Dayak Benuaq Kalimantan Timur. Manfaat Sistem Tradisional Dibandingkan Dedngan Sistem Alternatif. Jakarta.

Rimbawan, dan Y.F. Baliwati. 2004. Masalah Pangan dan Gizi. Pengantar Pangan dan Gizi. Penebar Swadaya. Bogor.

Sanjur, D. 1982. Social and Cultural Perspectives in Nutrition. PrenticeHall, Inc: New-Jersey.

Suhaimi, A. 2003. Kajian konsumsi pangan dan sosial ekonomi rumah tangga sebagai indikator kemiskinan di Kabupaten Kutai Kartanegara Kalimantan Timur. Kerjasama Puslit UVAYA. Banjarmasin.

Suhardjo.1992. Peranan pertanian dalam upaya mengatasi masalah pangan dan gizi. Pidato Penerimaan Jabatan Guru Besar, IPB, Bogor.

Widya Karya Nasional Pangan dan Gizi. LIPI. 2004. Prosiding Ketahanan Pangan dan Gizi di Era Otonomi Daerah dan Globalisasi. WKNPG VIII, Jakarta, 2004.

Wijaya, K., N Rosdiana dan B Lusiana. 2005. Cadangan Karbon Di Kabupaten Nunukan, Kalimantan Timur: Formacs. World Agroforestry Centre (ICRAF). Bogor. 